\title{
УДК 338.264
}

\section{ВИЗНАЧЕННЯ ВПЛИВУ ЕНЕРГЕТИЧНОЇ СТРАТЕГІЇ УКРАЇНИ НА ЕФЕКТИВНІСТЬ УПРАВЛІННЯ ПІДПРИЕМСТВОМ}

\author{
Наталія Тимошенко; Вікторія Фідря
}

\author{
Національний технічний університет Украӥни «Київський політехнічний \\ інститут імені Ігоря Сікорського», Київ, Украӥна
}

\begin{abstract}
Резюме. Статтю присвячено визначенню впливу енергетичної стратегії України на ефективність управління підприємством на прикладі компанії ДТЕК, яка є одним із ключових гравців енергетичного ринку Украӥни. Не зважаючи на постійну увагу держави до питань забезпечення енергетичної безпеки, краӥна все ще залишається вразливою до зовнішніх та внутрішніх загроз і викликів. Саме тому дослідження проблем та персектив розвитку енергетичного ринку, а також ефективності функиіонування його підприємств є вкрай актуальними в наш час. Стаття має прикладний характер, дослідження спирається на дані за останні роки. Наведено обсяги виробництва, динаміку експортуімпорту та споживання електроенергї в Украӥні за 2020-2021 роки. Детально досліджено енергетичний ринок Украйни та визначено ключові особливості його розвитку. Виявлено, щяо основними споживачами електроенергї в Україні виступають великі промислові підприємства та населення. Розкрито структуру ключових суб'єктів управління та регулювання в енергетичному секторі України. Проаналізовано державне регулювання ринку електроенергії в Україні, охарактеризовано форми державної допомоги, пільги та програми субсидій, щз діють в енергетичному секторі. Виділено основні иілі проекту «Енергетичної стратегії України на період до 2035 року» та здійснено його порівняння з попереденіми програмами й планами. Встановлено, щзо цільові параметри енергетичної стратегії краӥни повинні формуватися на основі енергетичного балансу, тобто системи показників, які характеризують ресурси, виробництво, надходження й використання всіх видів палива та енергії. Для аналізу впливу енергетичної стратегії країни на ефективність управління підприємством проаналізовано ключові фінансові показники за період 2017-2019 рр. енергетичної компанії ДТЕК, серед яких: дохід, витрати, собівартість реалізованої продукції, маржа, чистий прибуток, активи, капіталовкладення, сплачені податки та інші. Досягнення иілей енергетичної стратегії України в довготерміновій перспективі сприятиме зменшенню залежності від імпорту енергоресурсів, подоланню кризових явищ в економіці та підвищенню економічного потенціалу країни в иілому.
\end{abstract}

Ключові слова: енергетична стратегія, енергетичний ринок, споживання, виробництво, иілі розвитку, ефективність управління, ДТЕК, електроенергія, обсяги виробництва.

Отримано 21.09.2021

UDC 338.264

\section{DETERMINING THE IMPACT OF UKRAINE'S ENERGY STRATEGY ON THE EFFICIENCY OF ENTERPRISE MANAGEMENT}

\author{
Nataliia Tymoshenko; Victoria Fidrya
}

\author{
National Technical University of Ukraine «Igor Sikorsky Kyiv Polytechnic \\ Institute», Kyiv, Ukraine
}

Summary. The paper is devoted to the determination of the impact of Ukraine's energy strategy on the efficiency of enterprise management on the example of DTEK, which is one of the key participants in the energy market of Ukraine. Despite the country's constant attention to energy security, the country remains vulnerable to 
external and internal threats and challenges. That is why the investigation of problems and perspectives of energy market development, as well as the efficiency of its enterprises are extremely important at present. The paper has the applied nature, the research is based on current data of recent years. In particular, the paper presents production volumes, dynamics of export-import and electricity consumption in Ukraine in 2020-2021. The energy market of Ukraine is investigated in detail and the key features of its development are determined. It is determined that the main consumers of electricity in Ukraine are large industrial enterprises and the population. The structure and key participants of management and regulation in the energy sector of Ukraine are revealed in this paper. The state regulation of the electricity market in Ukraine is analyzed, the forms of state aid, benefits and subsidy programs operating in the energy sector are characterized. The main goals of "Energy Strategy of Ukraine for the period up to 2035» project are highlighted and compared with previous programs and plans. It is established that the target parameters of the country's energy strategy should be formed on the basis of energy balance, that is a system of indicators that characterize the resources, production, supply and use of all fuels and energy. To analyze the impact of the country's energy strategy on the efficiency of enterprise management, key financial indicators for the period 2017-2019 of DTEK energy company, including: income, expenses, cost of sales, margin, net profit, assets, investments, paid taxes and others are analyzed. Achievments of the goals of Ukraine's energy strategy in the long-term perspective will contribute to the reduction of dependence on energy imports, overcoming the crisis in economy and increase of the country economic potential as a whole.

Key words: energy strategy, energy market, consumption, production, development goals, management efficiency, DTEK, electricity, production volumes.

Received 21.09.2021

Постановка проблеми. У переломні для національної економіки моменти виробляється певний орієнтир, який згодом задає зміст енергетичної стратегіїдокумента державної енергетичної політики, який визначає цілі розвитку енергетичного сектора в довготерміновій перспективі. Загальносвітова тенденція до вичерпання традиційних енергоресурсів, українсько-російський газовий конфлікт 2005-2006 pp.усе це свого часу відіграло чималу роль у загостренні загальної уваги до необхідності підвищити енергетичну безпеку, що в кінцевому підсумку знайшло відображення в «Енергетичній стратегії України на період до 2030 року». Звідси не дивно, що «Енергетична стратегія України на період до 2035 року» у вигляді відповідного проекту позначилася саме зараз, в обставинах критичних змін в економічному й соціальному житті країни та компаній, які функціонують на енергетичному ринку України.

Аналіз останніх досліджень і публікацій. Питання про основні цілі енергетичної стратегії України досліджували багато зарубіжних та вітчизняних дослідників, зокрема: А. Онищенко [13], М. Булгакова [12], А. Денисенко, І. Ставчук, А. Шумейко та I. Головко [10] та інші. Проте незважаючи на наявні публікації, актуальним залишається визначення впливу енергетичної стратегії України на ефективність управління підприємством.

Метою дослідження с аналіз основних цілей енергетичної стратегії України та їх впливу на ефективність управління підприємством.

Постановка завдання. Для досягнення поставленої мети визначено такі наукові завдання: дослідити динаміку розвитку енергетичного ринку України; зробити комплексне дослідження державного регулювання електроенергії в Україні; проаналізувати основні цілі енергетичної стратегії України; дослідити вплив енергетичної стратегії на ефективність управління підприємством на прикладі компанії ДТЕК, яка є одним із ключових гравців енергетичного ринку України.

Виклад основного матеріалу. В Україні діє об'єднана енергетична система, яка $\epsilon$ сукупністю електростанцій: атомних, теплових, гідравлічних, гідроакумуляційних та тих, що працюють на поновлюваних джерелах енергії; теплоелектроцентралей, а також магістральних i розподільних електромереж. Обсяги виробництва електроенергії різними видами електростанцій за перший квартал 2020 та 2021 років показані на рисунку 1. 
На основі аналізу ринку електричної енергії за I квартал 2021 року бачимо, що обсяг виробництва електричної енергії в Україні становив 41961 тис. MWh, що є на 4\% більше, ніж в аналогічному періоді 2020 року [1].

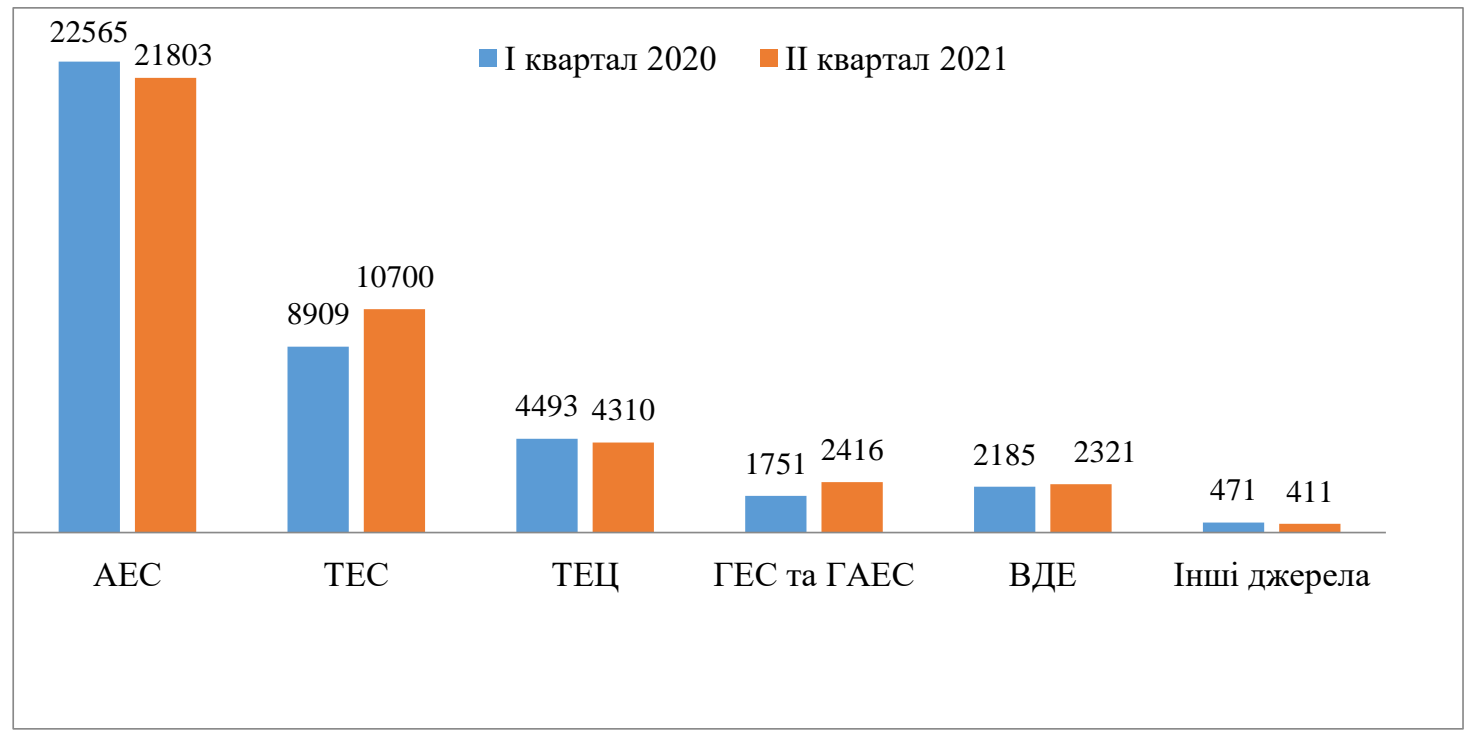

Рисунок 1. Обсяги виробництва електроенергії за 1 квартал 2020 та 2021 років, тис. MWh [1]

Figure 1. Volumes of electricity production for the first quarter of 2020 and 2021, thousand MWh [1]

У зв'язку з переходом на європейську модель ринку обленерго розділили монопольний і конкурентний вид діяльності, виділивши операторів системи розподілу й постачальників електроенергії.

Споживачами електроенергії $є$ в основному великі промислові підприємства та населення, які використовують ії задля задоволення своїх потреб та виробничих потужностей. Структура споживання електроенергії в Україні за 2020 показана рисунку 2.

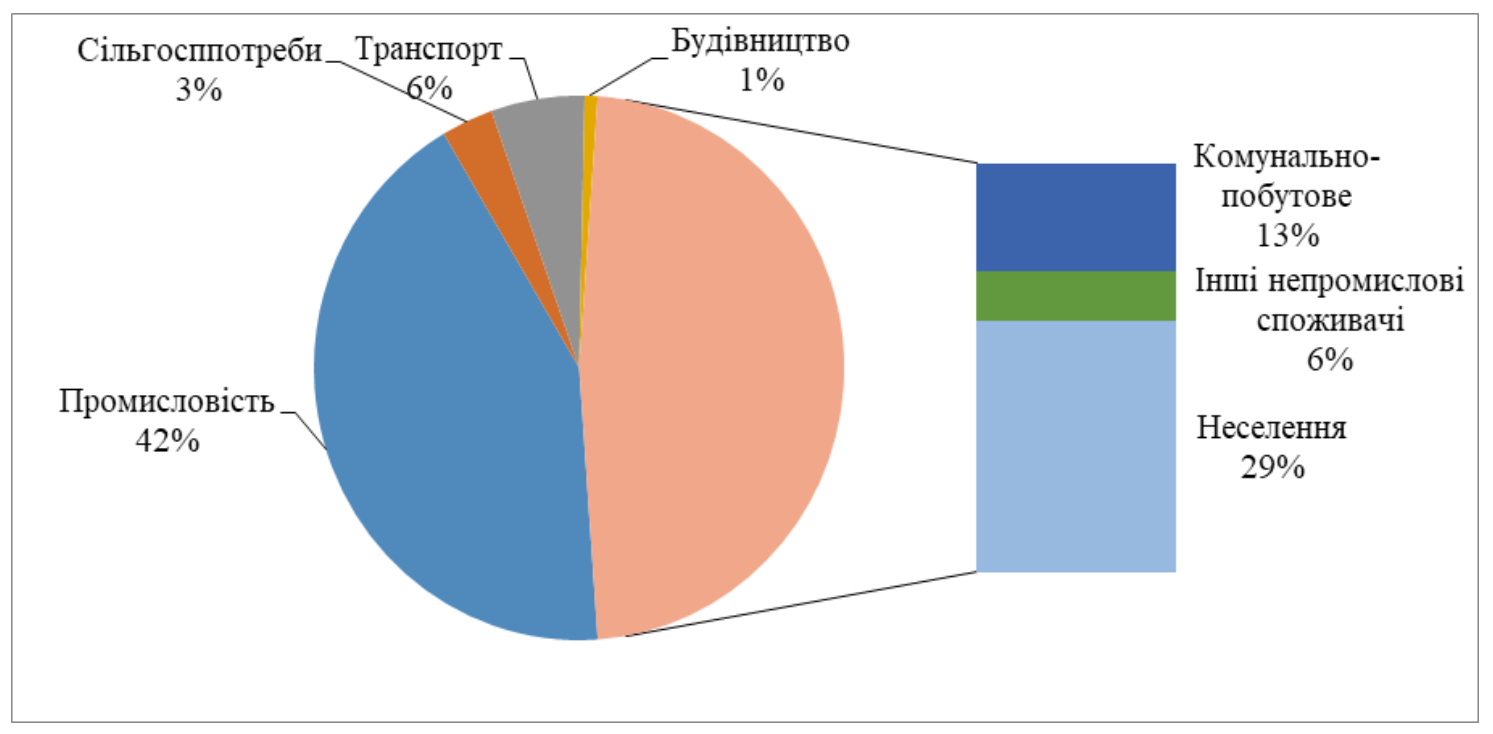

Рисунок 2. Структура споживання електроенергії в Україні за 2020 р., \% [1]

Figure 2. The structure of electricity consumption in Ukraine in 2020, \% [1] 
Згідно $з$ наведеним вище рисунком можна простежити, що значну частку в структурі споживання електроенергії займає промисловість (42\%), яка в основному $є$ одним із головних споживачів електроенергії. На другому місці знаходиться населення $29 \%$, трійку лідерів зі споживання завершує комунально-побутове споживання із часткою $13 \%$.

Щодо обсягу експортованої електричної енергії, то у І кварталі 2021 року іiї об’єм склав 559,9 тис. MWh, а імпортованої в рази більше - 907,5 тис. MWh (рис. 3). Також ми можемо спостерігати низькі обсяги експорту в січні - лютому 2021 року та шалене зростання в березні. Щодо імпорту, то його обсяги зросли на $90 \%$ у лютому в порівнянні з січнем та впали в 3,92 раза у березні в порівнянні з лютим. Порівняно 3 останнім кварталом 2020 року загальний обсяг експортованої електричної енергії зменшився на 57,2\%, а сумарний обсяг імпортованої електричної енергії своєю чергою збільшився на $118,9 \%$. Детальніше динаміку експорту та імпорту електроенергії за перший квартал 2021 року за країнами показано на рисунку 3.

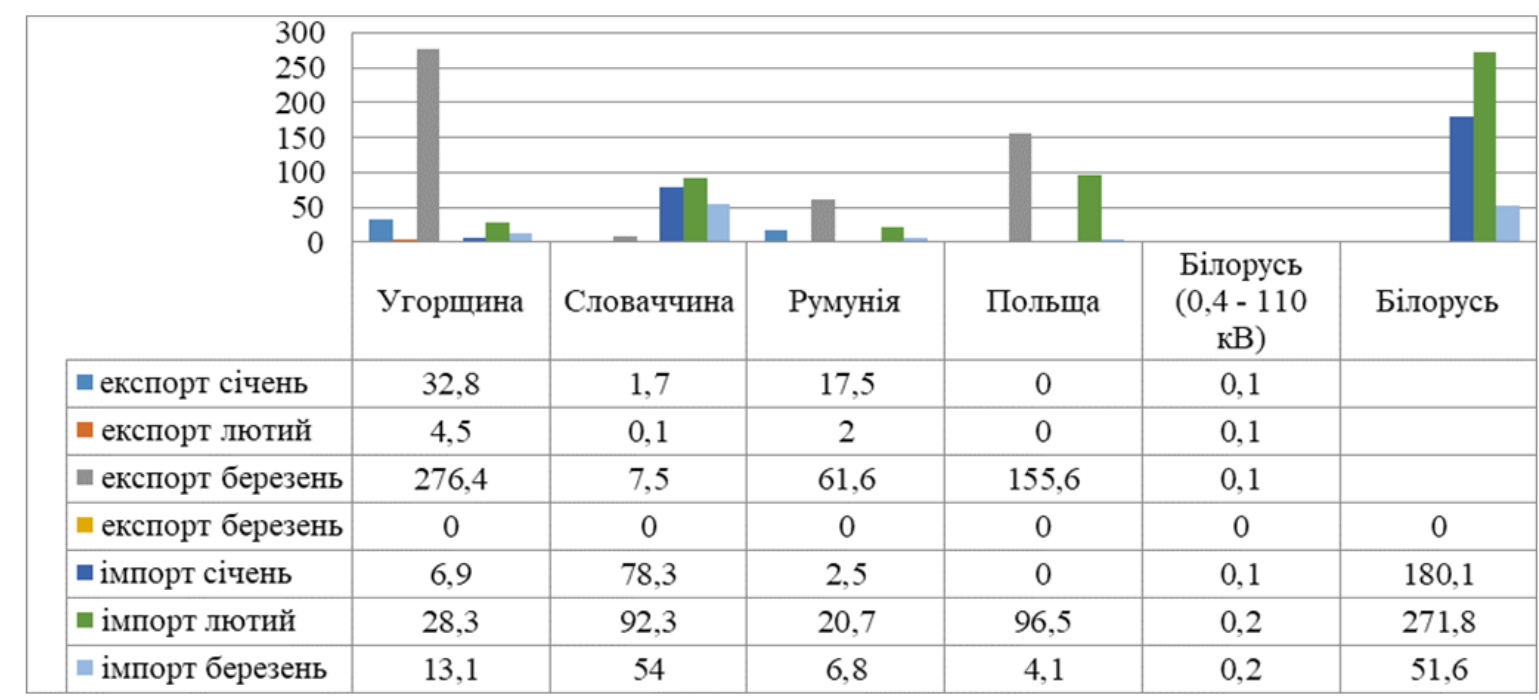

Рисунок 3. Динаміка експорту-імпорту електроенергії за перший квартал 2021 року, тис. MWh [1]

Figure 3. Dynamics of electricity export-import for the first quarter of 2021, thousand MWh [1]

3 наведеного вище рисунка бачимо, що в основному обсяг імпорту переважає обсяг експорту, що свідчить про недозавантаженість українських енергетичних компаній та їх неспроможність задовольнити потреби ринку.

Міністерство енергетики та вугільної промисловості України, як зазначено в прогнозному балансі електроенергії ОЕС, очікує збільшення обсягів експорту в 2021 році в порівнянні з 2020. Надалі сприяти збільшенню експортних постачань буде проект з приєднання України до континентальної синхронної частини європейської енергосистеми, який в основному спрямований на підвищення енергетичної безпеки країни та передбачає відділення від енергетичних систем РФ і Білорусі, з якими ОЕС України зараз працює в спільному режимі.

До ключових суб'єктів управління та регулювання в енергетичному секторі України належать Кабінет Міністрів України (КМУ), Міністерство енергетики та вугільної промисловості (Міненерговугілля) і Національна комісія, що здійснює державне регулювання у сферах енергетики та комунальних послуг (НКРЕКП). 
Міненерговугілля відповідає за формування та реалізацію політики в енергетичному секторі. Воно підзвітне КМУ, Верховній Раді (парламенту) та Адміністрації Президента [2]. Міненерговугілля також відповідає за розроблення Енергетичної стратегії України на період до 2035 року, відстеження та моніторинг результатів і подання річних звітів про стан іiі реалізації на розгляд КМУ та Ради національної безпеки і оборони України. Більше того, Міненерговугілля відповідає за вимірювання економічних стимулів, моніторинг і звітування про попит на енергію та прогнозні показники, а також визначає стратегію й методику будівництва енергогенерувальних установок. Воно тісно співпрацює 3 Державною інспекцією 3 енергетичного нагляду та КМУ в ході реалізації державної політики в секторі постачання електричної та теплової енергії та під час моніторингу безпеки постачання електричної енергії, в тому числі технічних аспектів діяльності обленерго в електроенергетичній галузі. Державна інспекція ядерного регулювання, зі свого боку, безпосередньо співпрацює з КМУ для забезпечення формування та реалізації державної політики у сфері ядерної безпеки [3, 2]. Детальніше структура управління енергетичного сектора України наведена на рисунку 4.

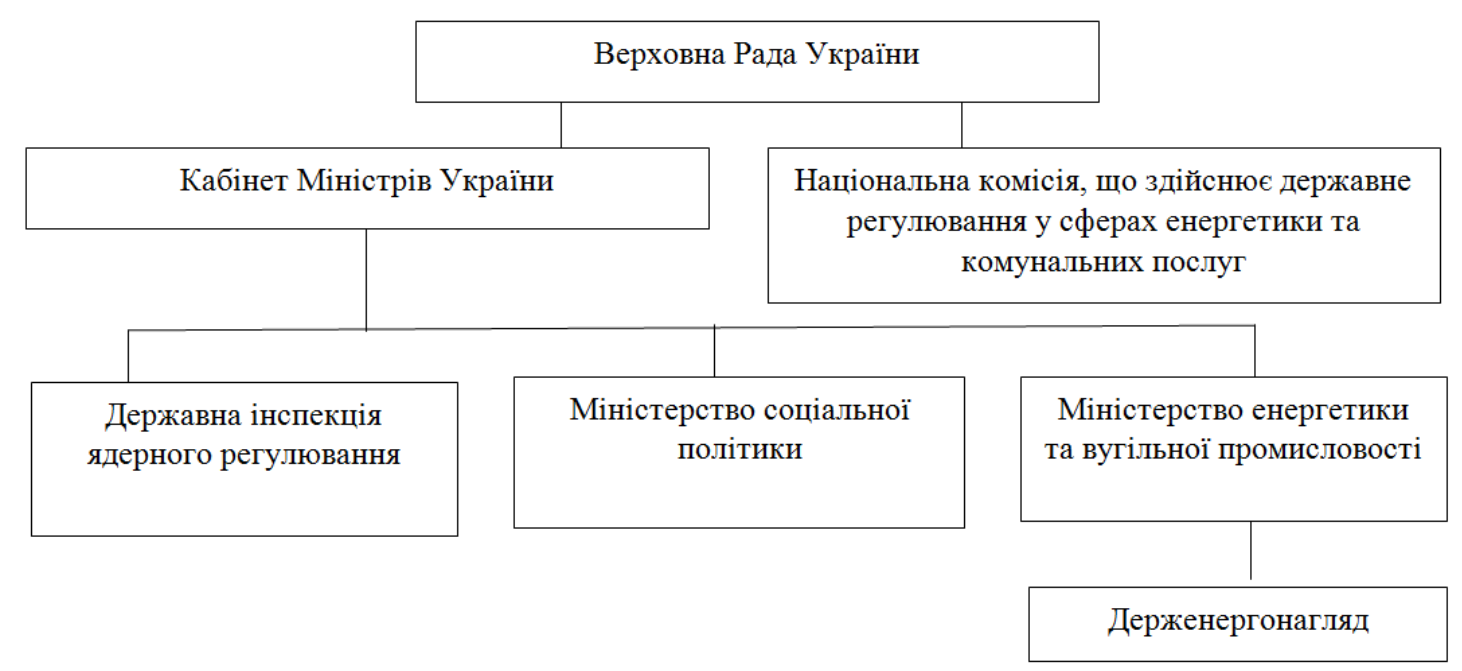

Рисунок 4. Структура управління в енергетичному секторі України

Figure 4. Management structure in the energy sector of Ukraine

Разом із КМУ та Міненерговугілля центральну роль у регулюванні енергетичного сектора країни також відіграє НКРЕКП, зокрема це стосується визначення тарифної політики та впровадження відповідних формул ціноутворення $[2,3]$. Наразі вона звітує перед Верховною Радою та співпрацює з КМУ, в той час як за Президентом збереглася непряма роль у призначенні членів Комісії $[4,5]$.

У контексті регулювання енергетичного сектора та управління ним Уряд України продовжує надавати державну допомогу учасникам ринку та споживачам. 3 метою підтримки низьких тарифів для кінцевих споживачів Україна запровадила інструменти контролю та масштабні програми субсидій. Суми коштів, що виділяються на такі програми, еквівалентні 7,5\% ВВП країни [6]. Разом з покладанням спеціальних обов'язків Україна надає додаткову допомогу соціально незахищеним споживачам у формі субсидій, які розраховуються, виходячи з розміру доходу домогосподарства та кількості його членів [7]. У той час, як КМУ відповідає за призначення субсидій, Міністерство соціальної політики розробляє та формулює політику надання побутовим 
споживачам допомоги у сплаті за житлово-комунальні послуги, в тому числі постачання природного газу, тепла, електроенергії та гаряче водопостачання. Житлові субсидії можуть надаватися або напряму споживачам, або місцевим бюджетам для забезпечення розрахунків з об’єднаннями, підрядниками та надавачами послуг [2].

Зважаючи на те, що політика уряду призвела до постачання енергоресурсів за нерентабельними цінами, уряд розробив також програми компенсації збитків компаніям, що займаються виробництвом, розподілом та постачанням енергії.

Разом $з$ державною допомогою та програмами субсидій, в енергетичному секторі застосовуються також податкові пільги. У 2015 році в Україні були запроваджені загальнодержавні, які застосовуються до суб'єктів, що діють у різних підсекторах енергетики. Наприклад, компанії, що займаються видобутком та перероблюванням вуглеводнів, зобов'язані сплачувати базові податки. Акцизний податок та рентна плата були встановлені здебільшого для компаній, які займаються видобутком природного газу, нафти та вугілля, проте їхні ставки відрізнялися залежно від виду продукту [8]. Окрім цього, у липні 2019 акцизний податок був запроваджений на ринку електроенергії [9]. Однак Україна надала податкові пільги та звільнення від оподаткування компаніям, що працюють із газовими та електромережами, а також тепловим електростанціям, для участі в інвестиційних програмах [8]. Більше того, у рамках діяльності зі стимулювання «зеленого» зростання Україна звільнила від оподаткування когенераційні установки та підприємства, що займаються виробництвом енергії 3 відновлюваних джерел.

Створення проекту «Енергетичної стратегії України на період до 2035 року» проходило в рамках виконання договору між Національним інститутом стратегічних досліджень та Об’єднанням енергетичних підприємств «Галузевий резервноінвестиційний фонд розвитку енергетики» (ОЕП «ГРІФРЕ») на замовлення Міністерства енергетики та вугільної промисловості України. Це означає, що проект $є$ продуктом роботи авторського колективу у складі співробітників НІСД, НАН України, тобто виключно державних установ.

Існують серйозні передумови до того, щоб нова стратегія могла вважатися більш адекватною, ніж її попередниці. По-перше, проект «Енергетичної стратегії України на період до 2035 року» є принципово новою розробкою, що дозволяє позиціювати його як звідення основ державної енергетичної політики, а не галузевий документ, яким була «Енергетична стратегія України на період до 2030 року» 3 iї подальшим відновленням [10]. По-друге, в основу проекту стратегії покладено сценарний підхід, який, на відміну від раніше існуючого відомчого підходу, поряд 3 особливостями розвитку національної економіки нашої країни враховує тенденції розвитку світового енергетичного ринку [11]. По-третє, положення документа розраховані на інтеграцію Директив СС в національне законодавство, що може посприяти виконанню зобов'язань, узятих на себе нашою державою в контексті залучення до Енергетичного співтовариства i підписання угоди про асоціацію. Цей перспективний документ був представлений громадськості з моменту публікації його тексту, що мало на меті провести проект через процедуру громадського обговорення, яка дозволила б розсудити, чи достатньо підстав оцінювати нову стратегію позитивно.

Наприклад, на думку колективу експертно-дорадчого центру «Правова аналітика», теперішній проект підтвердить свою спроможність не раніше, ніж будуть чітко позначені ті пункти угоди про асоціацію, які планується імплементувати в порядку виконання стратегії, адже тільки так контролююча, моніторингова або наглядова інстанція зможе дати висновок про виконання або невиконання того чи іншого зобов'язання. Втім, за великим рахунком мова йде про те, щоб сам процес виконання 
стратегії не виявився закритим і непрозорим, що не виключено, судячи з відсутності в проекті деяких вкрай важливих вказівок, серед яких [12]:

1) Джерела фінансування поставлених завдань і їх виконавці.

2) Процедура контролю над виконанням завдань і форма відповідальності за невиконання.

3) Процедура оскарження бездіяльності та наслідків, які спричинило за собою невиконання стратегії, порядок оскарження та його нормативне регулювання.

4) Обов’язок інформування громадськості про виконання стратегії, а також періодичність такого інформування.

Це $є$ непрямим свідченням потурання в нашій країні практиці жонглювання показниками, тим більше, що за вірогідність прогнозних даних поручитися складно. I свою роль тут відіграє та обставина, що за змістом документа не простежуються ні в описі джерел інформації, ні відомості про інструменти складання прогнозів зростання економіки і зростання споживання паливно-енергетичних ресурсів.

Встановити обгрунтовані чи ні положення проекту нової стратегії можна в тому випадку, якщо до інформації, що є вихідною, ввести критерій суттєвості. Застосування цього критерію має на увазі наявність у цій інформації якоїсь характеристики, упущення або спотворення якої може стати причиною хибного тлумачення інформації іiі користувачами. I й, оскільки будь-яка інформація є підгрунтям для прийняття рішень, про обгрунтованість тих чи інших положень слід судити саме за якістю подання такої інформації.

Наявність взаємозв'язку між прогнозним рівнем енерговитрат і прогнозом зростання ВВП є очевидним. Однак саме по собі прогнозне зростання ВВП не доводить зростання енергоспоживання, тим більше, що задане проектом нової стратегії зростання ВВП за 20 років в 2 рази (або 3,5\% в рік) навряд чи можна назвати зростанням в порівнянні, наприклад, з Китаєм, де показник зростання ВВП на рік становить 7,5\% [13]. Та й на тлі країн Євросоюзу і США, де в основі точно такого ж 3,5\% щорічного зростання лежить економічна стабільність, Україна навіть при стабільності економічної ситуації в плановий період буде відставати.

Для України осмислення різниці між вітчизняним та зарубіжним підходами могло б покласти початок курсу на зниження або хоча $б$ стабілізацію споживання енергоресурсів, особливо в разі зростання ВВП за рахунок виробництв, де існують резерви зниження.

Однак чи є такі резерви насправді - невідомо, адже «Енергетичною стратегією України на період до 2035 року» не визначено, якими галузями планується забезпечувати приріст вітчизняного ВВП. Якщо б це були галузі підвищеної енергомісткості, збільшення енергоспоживання було б обгрунтованим. Але у тому й справа, що одного прогнозного балансу споживання паливно-енергетичних ресурсів на період до 2035 року, без розкриття структури освіти ВВП галузями національної економіки, недостатньо для перевірки обгрунтованості прогнозного збільшення енергоспоживання.

Очевидно, що цільові параметри енергетичної стратегії країни повинні формуватися на основі енергетичного балансу, тобто системи показників, які характеризують ресурси, виробництво, надходження й використання всіх видів палива та енергії. I по тому, чи узгоджені між собою відповідні документи, можна з чіткістю визначити, чи простежується в цих параметрах вплив такої якості інформації, як істотність. Наше дослідження будувалося на припущенні про наявність у проекті «Енергетичної стратегії України на період до 2035 року» суттєвої інформації, яка б давала ключ до розпізнавання суті вибору авторами стратегії тих чи інших рішень в якості ¥ї цільових параметрів. Адже цей вибір міг бути мотивований як необхідністю досягнення цілей розвитку паливно-енергетичного комплексу, так і необхідністю 
дотримання інтересів певних груп впливу, що підтверджується оцінкою попередніх стратегій з критичної перспективи.

Однак, як з'ясувалося, можливості перевірити обгрунтованість найголовніших цільових параметрів у нас не виявилося, так як не виявилося в стратегії суттєвої інформації щодо цих параметрів. I те, що проблема переноситься в площину пошуку самих підстав для того чи іншого прогнозу, найімовірніше свідчить про те, що дана стратегія не $\epsilon$ програмою державної енергетичної політики в строгому сенсі цього поняття. Якщо б вона була такою, тоді ця стратегія узгоджувалася б із загальними стратегіями економічного й соціально-політичного розвитку країни, принцип системності був би дотриманий, а значить, нам не довелося б шукати відповіді на запитання про те, чим керуються розробники стратегії при виборі певних стратегічних рішень.

Для аналізу впливу енергетичної стратегії на ефективність управління підприємством пропонуємо проаналізувати ключові фінансові показники енергетичної компанії ДТЕК, яка напряму пов'язана з ефективністю енергетичної стратегії України (див. табл. 1).

Таблиця 1. Аналіз фінансових показників ТОВ «ДТЕК» за період 2017-2019 рр., млн грн

Table 1. Analysis of financial indicators of DTEK LLC for the period 2017-2019, million UAH

\begin{tabular}{|l|c|c|c|c|c|c|c|}
\hline \multirow{2}{*}{ Основні показники } & \multicolumn{3}{|c|}{ Роки } & \multicolumn{2}{c|}{$\begin{array}{c}\text { Абсолютне } \\
\text { відхилення, }\end{array}$} & \multicolumn{2}{c|}{$\begin{array}{c}\text { Відносне } \\
\text { відхиленн, \% }\end{array}$} \\
\cline { 2 - 8 } & 2017 & 2018 & 2019 & $\begin{array}{c}2019 / \\
2017\end{array}$ & $\begin{array}{c}2019 / \\
2018\end{array}$ & $\begin{array}{c}2019 / \\
2017\end{array}$ & $\begin{array}{c}2019 / \\
2018\end{array}$ \\
\hline Дохід & 134637 & 157619 & 189876 & 55239 & 32257 & 141,03 & 120,47 \\
\hline Собівартість реалізованої продукції & -100783 & -121273 & -132456 & -31673 & -11183 & 131,43 & 109,22 \\
\hline Операційний дохід & 1225 & 571 & 890 & -335 & 319 & 72,65 & 155,87 \\
\hline Операційні витрати & -14329 & -13211 & -14340 & -11 & -1129 & 100,08 & 108,55 \\
\hline ЕВІТDА & 37195 & 42897 & 44356 & 7161 & 1459 & 119,25 & 103,40 \\
\hline Маржа ЕВІТDА & $28 \%$ & $27 \%$ & $27 \%$ & 0 & 0 & 96,43 & 100,00 \\
\hline ЕВІТ & 26484 & 28303 & 29765 & 3281 & 1462 & 112,39 & 105,17 \\
\hline Маржа ЕВІТ & $20 \%$ & $18 \%$ & $20 \%$ & 0 & 0 & 100,00 & 111,11 \\
\hline Чистий прибуток & 4628 & 12373 & 13456 & 8828 & 1083 & 290,75 & 108,75 \\
\hline Активи & 152492 & 147971 & 149600 & -2892 & 1629 & 98,10 & 101,10 \\
\hline Капіталовкладення & 10388 & 19878 & 22453 & 12065 & 2575 & 216,14 & 112,95 \\
\hline Податки, сплачені в Україні & 22517 & 26724 & 31646 & 9129 & 4922 & 140,54 & 118,42 \\
\hline
\end{tabular}

Джерело: розроблено авторами за $[14,15,16]$.

Чистий прибуток ДТЕК за перше півріччя 2019 року склав 3,3 млрд грн, що на $38,2 \%$ менше, ніж за перше півріччя 2018 р. Це пов'язано в основному із падінням курсу євро та долара в Україні, а також з тим фактом, що більшість енергії експортується, а курсова різниця дорівнює 1,4 млрд грн.

Собівартість продукції у 2019 році зросла на 9,22\% порівняно 32019 роком, збільшивши обсяг виробництва в 2019 році на 8,55\%. Однак на тлі збільшення витрат чистий прибуток компанії зріс на 8,75\%, головним чином шляхом збільшення продажів та сукупних доходів. Сьогодні за більшістю економічних показників (рентабельність, ліквідність, платоспроможність) ТОВ «ДТЕК» можна вважати досить фінансово стабільним. 
Згідно з аналізом фінансового стану ДТЕК та його позитивної динаміки можемо констатувати, що компанія розвивається плавно, отримуючи високі прибутки при відносно нижчих витратах. Отже, запровадження енергетичної стратегії розвитку країни позитивно вплинуло на розвиток компанії, в основному на збільшення виробництва електроенергії, яка є ключовою ціллю описаної вище стратегії.

Висновки. Простежується суттєвий вплив енергетичної стратегії країни на діяльність підприємств енергетичного ринку. Виходячи 3 наведених даних, iз запровадженням нової енергетичної стратегії України до 2035 виробництво електроенергії повинно зрости кратно зростанню ВВП, при цьому при рівномірному збільшенні їі експорту та імпорту. Дане зростання позитивно впливатиме на розвиток компаній, які працюють на енергетичному ринку України, адже при збільшенні попиту з боку споживачів прямопропорційно зростатиме пропозиція від компаній енерговиробників. Дане зростання позитивно впливатиме на загальний фінансовий стан компаній та відповідно підвищуватиме їх конкурентоспроможність як на українському, так і на експортному ринках.

Серед важливих заходів слід зазначити необхідність постійної координації розвитку структури державного управління та адаптації поточних цілей до зовнішньої ситуації, в тому числі розробленні заходів мінімізації негативного впливу та протидію ризикам, що сприятиме досягненню завдань та цілей енергетичної стратегії України. Досягнення цілей енергетичної стратегії України в довготерміновій перспективі сприятиме зменшенню залежності від імпорту енергоресурсів, подоланню кризових явищ в економіці та підвищенню економічного потенціалу країни в цілому.

Conclusions. From the carried out investigation we can conclude that there is a significant impact of the country's energy strategy on the activities of energy market enterprises. On the basis of the above given data, we can conclude that the introduction of new energy strategy of Ukraine until 2035 should enlarge the electricity production in multiples of GDP growth, with the steady increase in its exports and imports. This growth will have a positive impact on the development of companies operating in the energy market of Ukraine, because the increasing consumers demand will enlarge the supply of energy companies in direct proportion. This growth will also have a positive impact on the overall financial condition of companies and will increase their competitiveness in both Ukrainian and export markets.

Among the important measures we should note the need for constant coordination of the public administration development and adaptation of current goals to the external situation, including the development of measures to minimize the negative impact and counter risks, which will help to achieve the goals and objectives of Ukraine's energy strategy. The achievement of the goals of Ukraine's energy strategy in long term will promote the reduce of dependence on energy imports, overcoming the crisis in economy and increase of the country economic potential as a whole.

\section{Список використаної літератури}

1. Звіт з моніторингу функціонування оптового ринку електричної енергії у I кварталі 2021 року. (2021). URL: https://www.nerc.gov.ua/data/filearch/monitoryng/elektro/2021/monitoryng_ elektro_I-2021.pdf.

2. MECI (2019), Questionnaire for the OECD Project on Supporting Energy Sector Reform in Ukraine. (2019). URL: https://www.oecd.org/eurasia/competitiveness-programme/eastern-partners /supporting-energy-sector-reform-ukraine.htm. 
3. Ukrenergo /Ministry of Finance (2019), Questionnaire on the OECD Project Supporting Energy Sector Reform in Ukraine. (2019). URL: https://www.oecd.org/eurasia/competitiveness-programme/ eastern-partners/Snapshot-of-Ukraines-Energy-Sector-EN.pdf.

4. Energy Community (2018), The National Energy Regulatory: Governance and Independence, Energy Community. (2019). URL: https://www.energy-community.org/dam/jcr:6eb10b22-ca6a-4c43-8c9ff3614 dab3c91/ECS_NEURC_reg_report_032018.pdf.

5. Verkhovna Rada (2016), Law of Ukraine About the National Commission for State Regulation of Energy and Utilities. No. 1540-VIII. (2016). URL: https://zakon.rada.gov.ua/laws/show/1540-19.

6. OECD (2019), State-Owned Enterprise Reform in the Hydrocarbons Sector in Ukraine, OECD Publishing. (2019). URL: http://www.oecd.org/corporate/SOE-Reform-in-the-HydrocarbonsSector-in-Ukraine-ENG.pdf.

7. Teplo (n.d.), How is the subsidy calculated? (2019). URL: https://teplo.gov.ua/subsidies/yakrozrakhovuietsia-rozmir-subsydii.

8. OECD (2018), Inventory of Energy Subsidies in the EU's Eastern Partnership Countries, OECD Publishing. (2018). URL: https://doi.org/10.1787/9789264284319-en.

9. State Fiscal Service (2019), Starting July 1, electricity sales are subject to excise duty. (2019). URL: http://ck.sfs.gov.ua/media-ark/news-ark/382869.html.

10. Денисенко А., Ставчук І., Шумейко А., Головко І. Коментарі та пропозиції нецУ щодо проекту енергетичної стратегії України на період до 2035 року: аналітична доповідь. К.: Національний екологічний центр України, 2015. URL: http://necu.org.ua/wp-content/uploads/NECU_proposals _energy_strategy2035.pdf.

11. Результати першого року президентства Петра Порошенка. Міжнародний центр перспективних досліджень. Inside Ukraine. 2015. № 48 (2015). URL: http://icps.com.ua/assets/uploads/files/IU48_ UA_1099.pdf.

12. Булгакова М. Коментарі та пропозиції до проекту енергетичної стратегії України на період до 2035 року. Львів: експертно-дорадчий центр «правова аналітика», 2015. URL: http://legalanalytics. com.ua/images/comments.pdf.

13. Онищенко А. «Энергетическая стратегия Украины» - путь в пропасть. Национальный антикоррупционный портал. 2015. URL: https://antikor.com.ua/.

14. Annual financial reports of DTEK LLC for 2019. (2019). URL: https://dtek.com/ investors_and_partners/reports/.

15.DTEK LLC's annual financial statements for 2018. (2018). URL: https://dtek.com/investors _ and_partners/reports/.

16. Annual financial statements of DTEK LLC for 2017. (2017). URL: https://dtek.com/investors_and _partners/reports/.

\section{References}

1. Zvit z monitoryngu funkcionuvannya optovogo rynku elektrychnoyi energiyi u I kvartali 2021 roku. (2021). URL: https://www.nerc.gov.ua/data/filearch/monitoryng/elektro/2021/monitoryng_elektro_I-2021.pdf.

2. MECI (2019), Questionnaire for the OECD Project on Supporting Energy Sector Reform in Ukraine. (2019). URL: https://www.oecd.org/eurasia/competitiveness-programme/eastern-partners/supportingenergy-sector-reform-ukraine.htm.

3. Ukrenergo /Ministry of Finance (2019), Questionnaire on the OECD Project Supporting Energy Sector Reform in Ukraine. (2019). URL: https://www.oecd.org/eurasia/competitiveness-programme/easternpartners/Snapshot-of-Ukraines-Energy-Sector-EN.pdf.

4. Energy Community (2018), The National Energy Regulatory: Governance and Independence, Energy Community. (2019). URL: https://www.energy-community.org/dam/jcr:6eb10b22-ca6a-4c43-8c9f-f3614 dab3c91/ECS_NEURC_reg_report_032018.pdf.

5. Verkhovna Rada (2016), Law of Ukraine About the National Commission for State Regulation of Energy and Utilities. No. 1540-VIII. (2016). URL: https://zakon.rada.gov.ua/laws/show/1540-19.

6. OECD (2019), State-Owned Enterprise Reform in the Hydrocarbons Sector in Ukraine, OECD Publishing. (2019). URL: http://www.oecd.org/corporate/SOE-Reform-in-the-Hydrocarbons-Sector-in-UkraineENG.pdf. 
7. Teplo (n.d.), How is the subsidy calculated? (2019). URL: https://teplo.gov.ua/subsidies/yakrozrakhovuietsia-rozmir-subsydii.

8. OECD (2018), Inventory of Energy Subsidies in the EU's Eastern Partnership Countries, OECD Publishing. (2018). URL: https://doi.org/10.1787/9789264284319-en.

9. State Fiscal Service (2019), Starting July 1, electricity sales are subject to excise duty. (2019). URL: http://ck.sfs.gov.ua/media-ark/news-ark/382869.html.

10. Denysenko A., Stavchuk I., Shumejko A., Golovko I. Komentari ta propozyciyi shhodo proektu energetychnoyi strategiyi Ukrayiny na period do 2035 roku : analitychna dopovid. K.: Nacionalnyj ekologichnyj centr Ukrayiny, 2015. URL: http://necu.org.ua/wp- content/uploads/NECU_proposals_ energy_strategy2035.pdf.

11. Rezultaty pershogo roku prezydentstva Petra Poroshenka. Mizhnarodnyj centr perspektyvnyx doslidzhen. Inside Ukraine. 2015. No. 48. URL: http://icps.com.ua/assets/uploads/files/IU48_UA_1099.pdf.

12. Bulgakova M. Komentari ta propozyciyi do proektu energetychnoyi strategiyi Ukrayiny na period do 2035 roku. Lviv: ekspertno-doradchyj centr "pravova analityka", 2015. URL: http://legalanalytics.com.ua/ images/comments.pdf.

13. Onyshhenko A. “Эnergetycheskaya strategyya Ukrayny” - put v propast. Nacyonalnyj antykorrupcyonnyj portal. (2015). URL: https://antikor.com.ua/.

14. Annual financial reports of DTEK LLC for 2019. (2019). URL: https://dtek.com/investors and_partners/reports/.

15. DTEK LLC's annual financial statements for 2018. (2018). URL: https://dtek.com/investors_ and_partners/reports/.

16. Annual financial statements of DTEK LLC for 2017. (2017). URL: https://dtek.com/investors_and_ partners/reports/. 